\title{
Schizaraeus fouquei sp. nov., the first record of Schizaraeus from Peru (Coleoptera: Tenebrionidae: Stenosini)
}

\author{
Alfredo E. GIRALDO-MENDOZA ${ }^{1)}$ \& Gustavo E. FLORES ${ }^{2,3)}$ \\ 1) Universidad Nacional Agraria La Molina, Museo de Entomología Klaus Raven Büller, Av. La Molina s/n, Lima 12, Lima, Perú; \\ e-mail: alfre2cotobius@yahoo.com \\ ${ }^{2)}$ CONICET, Laboratorio de Entomología, Instituto Argentino de Investigaciones de las Zonas Áridas (IADIZA, CCT CONICET Mendoza), Casilla \\ de correo 507, 5500 Mendoza, Argentina; e-mail: gflores@mendoza-conicet.gov.ar \\ ${ }^{3)}$ corresponding author
}

\begin{abstract}
Accepted:
$5^{\text {th }}$ February 2020

Published online: $10^{\text {th }}$ March 2020
\end{abstract}

\begin{abstract}
A new species of Stenosini (Coleoptera: Tenebrionidae: Pimeliinae), Schizaraeus fouquei sp. nov. is described from southern Andes of Peru: Apurímac and Cusco regions. Prior to this study, Schizaraeus Kulzer, 1955 was monotypic with one species, S. acuticosta Kulzer, 1955 from Catamarca Province in Argentina. We present habitus photographs of both species, scanning electron micrographs of external morphology of the new species, a distribution map, and a comparison of the characters of both species of the genus.
\end{abstract}

Key words. Coleoptera, Tenebrionidae, Pimeliinae, Stenosini, Schizaraeus, new species, taxonomy, description, Peru, Neotropical Region

Zoobank: http://zoobank.org/urn:1sid:zoobank.org:pub:38FE2619-4D0D-44EC-81C8-757D361D1E71

(C) 2020 The Authors. This work is licensed under the Creative Commons Attribution-NonCommercial-NoDerivs 3.0 Licence.

\section{Introduction}

The tribe Stenosini is a tenebrionid group composed of small species with pantropical distribution, often associated with ants, rodent nests and soil (MatTHEws et al. 2010). The genus Schizaraeus Kulzer, 1955 is an interesting South American taxon, which until now included only one species - S. acuticosta Kulzer, 1955 (Fig. 1) described from two specimens collected in the Catamarca Province of Argentina (Kulzer 1955). Due to the small number of specimens available, the behavior and the ecology of the genus is unknown.

In the original description, KULzer (1955) compared Schizaraeus with the North American genus Araeoschizus LeConte, 1851, which contains 52 species and subspecies (BOUSQUET et al. 2018) associated with ant colonies inhabiting sandy desert areas (PAPP 1981). However, similarities with this genus are found only in dorsal general appearance, due costate and coarsely punctate elytra, which are very similar in both genera. According to NABOZHENKO et al. (2016) and AALBU et al. (2017), within American Stenosini Schizaraeus is morphologically related to the genera Grammicus Waterhouse, 1845, Ecnomoderes Gebien, 1928, Caribanosis Nabozhenko et al., 2016 and Renefouqueosis Aalbu et al., 2017 and placed in the sub- tribe Stenosina, which has the eyes either not divided, or divided but connected by a deep furrow. The remaining two South American genera Hexagonochilus Solier, 1851 and Discopleurus Lacordaire, 1859 as well as Araeoschizus are placed in the subtribe Dichillina as they have the eyes completely divided.

The objective of this paper is to describe an unexpected new species of Schizaraeus collected in southern Andes of Peru, to compare it with the known species from Argentina, to illustrate the main morphological traits of the genus using SEM images, and to provide distributions of both species in South America.

\section{Material and methods}

Body length was measured dorsally, along the midline, from the anterior margin of labrum to the apex of elytra; body width was measured behind humeri. Terminology used in the descriptions follows the two recent papers dealing with Stenosini (NABOzHENKo et al. 2016, AALBU et al. 2017). Terminology of female genitalia was taken from Doyen (1994).

Digital images were taken with a Canon S50 adapted to a Leica MZ6 stereomicroscope. Final images (Figs 1-2) were montaged with the image stacking freeware 
CombineZM (Hadley 2006). SEM pictures (Figs 3-10) of a paratype specimen of the new species were obtained using a JEOL JSM-6610 LV scanning electron microscope. Exact label data are cited for the type material of the new species; a single vertical bar (|) separates rows within each label and a double vertical (\|) separates individual labels. Distributional map was prepared using SimpleMappr (SHORTHOUSE 2010). For distribution of the species we used the biogeographic classification of Morrone (2014).

Type specimens are deposited in the following collections:

IADIZA Instituto Argentino de Investigaciones de las Zonas Áridas, Mendoza, Argentina;

MEKRB Museo de Entomología Klaus Raven Büller, Universidad Nacional Agraria La Molina, Lima, Perú;

NHMB Natural History Museum, Basel, Switzerland;

NMPC National Museum, Praha, Czech Republic;

VMDM V. Manuel Diéguez M. provate collection, Santiago, Chile.

\section{Taxonomy}

\section{Schizaraeus acuticosta Kulzer, 1955 (Fig. 1)}

Schizaraeus acuticosta Kulzer, 1955: 480 (original description).

Type locality. Argentina, Catamarca Province, Santa María Department, Caspinchango.

Type material. HolotyPE (Fig. 1): 'Argentina: Catamarca, Dpto. Santa María, Caspinchango, leg. Weiser' (NHMB). Studied only from photo of dorsal aspect provided by courtesy of René Fouquè. Additional material examined. ARGENTINA: LA RioJa: Dpto. Arauco, Arauco, $10 \mathrm{~km} \mathrm{~S}$ of Aimogasta, ii.1938, $1 \mathrm{spec}$. (IADIZA). SALTA: Dpto. Rosario de Lerma, Ingeniero Maury, $24^{\circ} 39.97^{\prime} \mathrm{S}, 65^{\circ} 47.21^{\prime} \mathrm{W}, 2367$ m, 22.xi.2005, 1 spec., A. González lgt. (IADIZA, donated by Instituto para el Estudio de la Biodiversidad de Invertebrados, Universidad Nacional de Salta).

Differential diagnosis. We mention only the features different from $S$. fouquei sp. nov.: antennomere III twice as wide at the apex than at the base; pronotum with lateral margins curved in anterior $2 / 3$ and narrowed in posterior third, anterior angles rounded and posterior angles straight. Description. See Kulzer (1955).

Distribution. Argentina: La Rioja, Catamarca and Salta provinces (Fig. 11), in localities belonging to the biogeographic province of Monte.

\section{Schizaraeus fouquei sp. nov.} (Figs 2-10)

Type locality. Peru, Cusco Region, Quispicanchi Province, Lucre District, Huacarpay, aprox. $3020 \mathrm{~m}$ a.s.l.

Type material. HoLOTYPE: 'PERU, Cusco, Quispicanchi | Lucre Huacarpay, aprox. 3020 m | E. Yábar coll. 10.viii.1982 || Schizaraeus |fouquei n. sp. | HOLOTYPUS | Det. A. Giraldo and | G. Flores 2018' (MEKRB). PARATYPES: 3 spec., same data as the holotype, (2 MEKRB, 1 IADIZA); 6 spec., 'PERU Apurímac| Curahuasi $2585 \mathrm{~m} \mid 28-30 . i v .2012$ | Leg. V. M. Diéguez | Habitos nocturno || Schizaraeus | fouquei n. sp. | PARATYPUS | Det. A. Giraldo and | G. Flores 2018' (3 VMDM, 1 NMPC, 1 IADIZA, 1 NHMB).
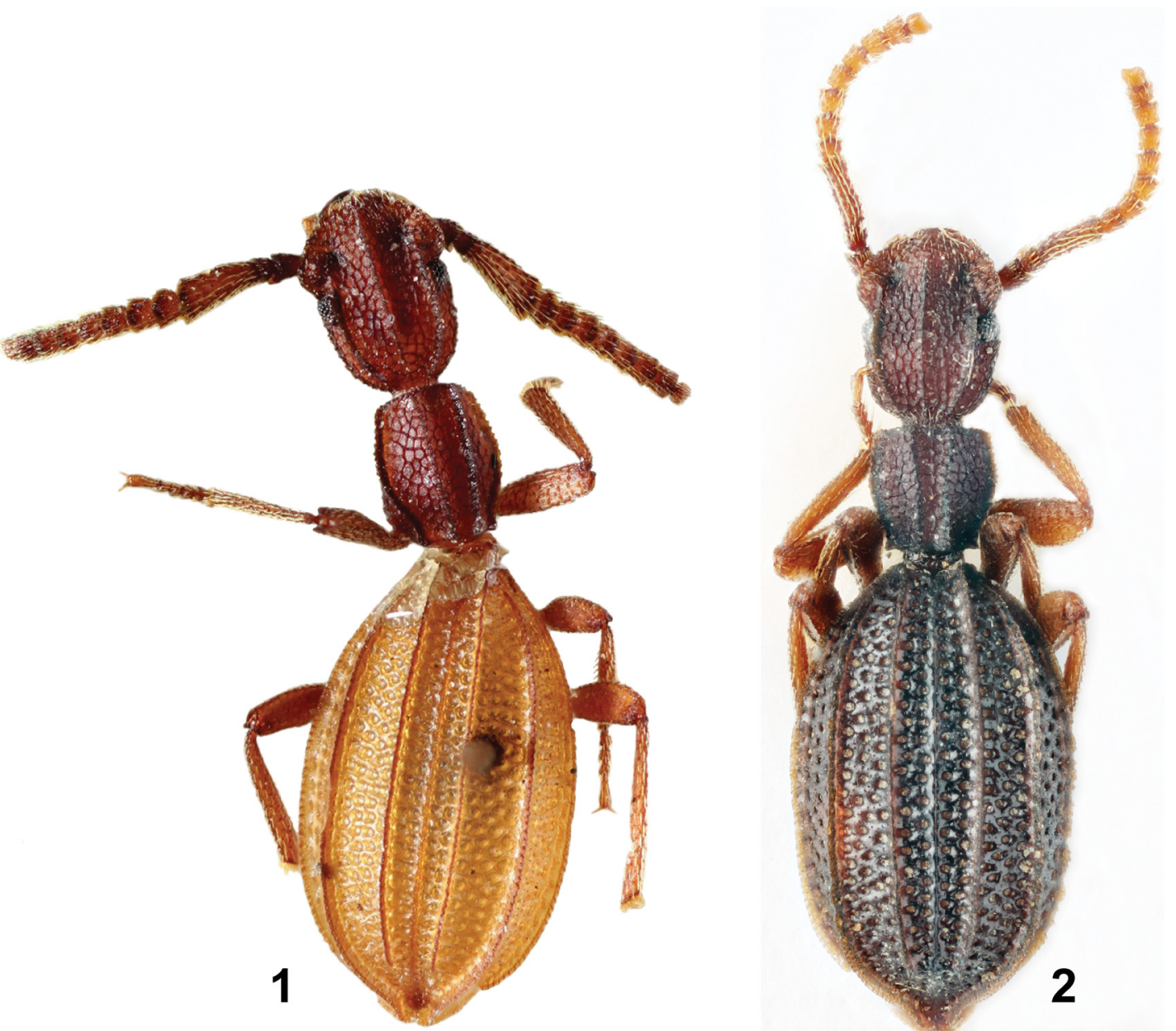

Figs 1-2. Dorsal habitus. 1 - Schizaraeus acuticosta Kulzer, 1955, holotype (NHMB); 2 -S. fouquei sp. nov., paratype NMPC. Fig. 1 provided by courtesy of René Fouquè; Fig. 2 taken by NMPC staff. 
Description. Small, elongate, glabrous, apterous; light to dark ferrugineous-brown. Head, pronotum narrow, abdomen pyriform (Fig. 3). Length: 4.7-5.0 $\mathrm{mm}(\mathrm{n}=10)$.

Head (Figs 4-6) long, oval, widest at epicanthus, longer, wider than pronotum, sides slightly curved (Fig. 4). Eyes small, round, convex, not divided, sharply faceted (21-24 facets in six rows) (Fig. 5), in the middle of lateral sides of head, each one limited dorsally by longitudinal keel (ocular ridge), ventrally by carinated margin of postgenae. Genae continuous with anterior margin of clypeus, ending on anterior margin of eyes. Clypeus with anterior margin truncate, armed with row of teeth. Frons, vertex with longitudinal keel at midline. Antennae thick, flattened, moderately covered with long hairs, slightly exceeding base of pronotum, with shallow coalescent punctures, giving reticulate appearance. Antennomere I thick, longer than wide; antennomere II short, wider than long; antennomere III thick, longer than wide, as long as IV-VI combined, 1.3 times as wide at apex
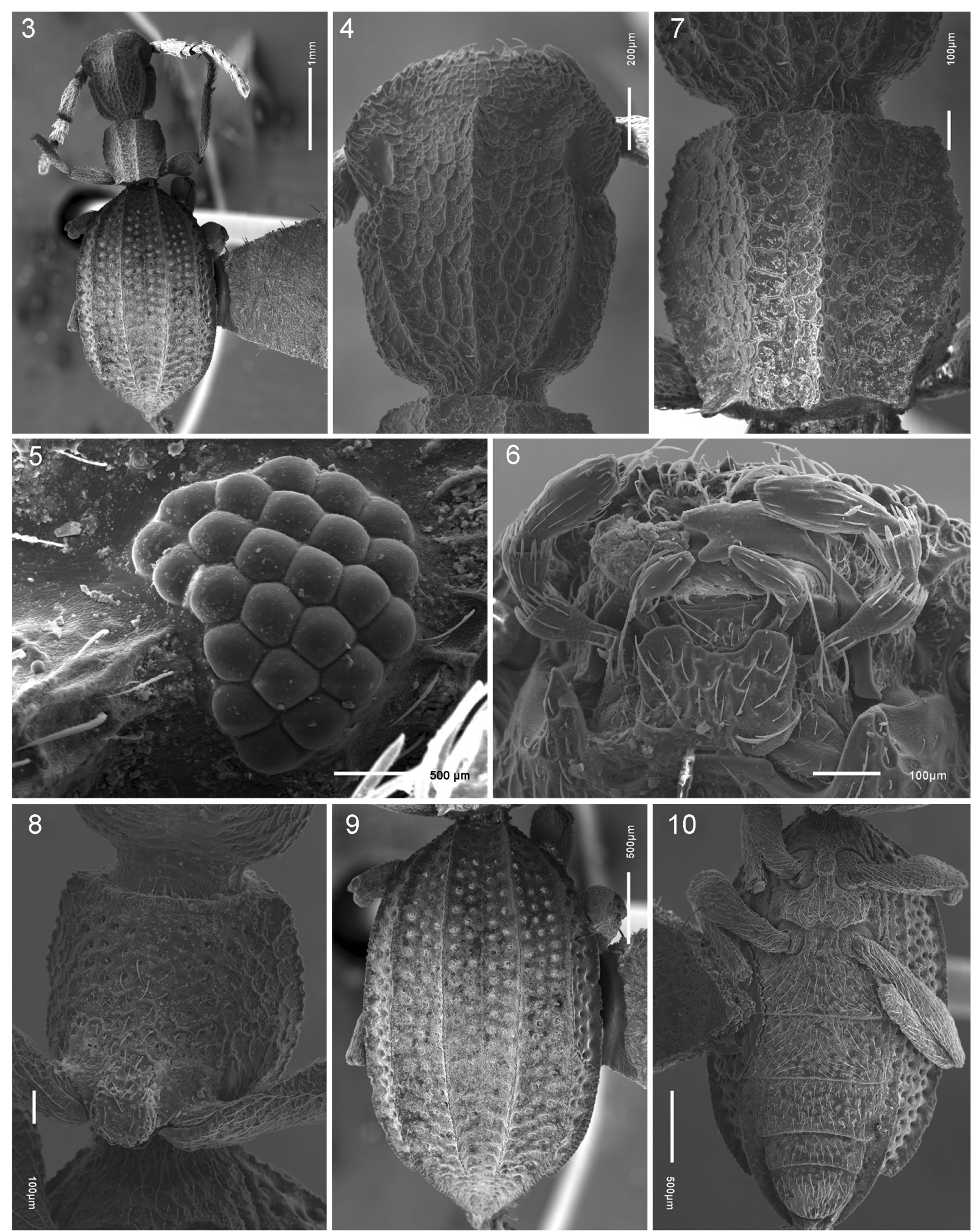

Figs 3-10. SEM images of $S$. fouquei sp. nov.: 3 - habitus $25 \times ; 4$ - head dorsal $95 \times ; 5$ - eye $500 \times ; 6$ - mouthparts $180 \times ; 7$ - pronotum $120 \times ; 8$ - prosternum 100×; 9 - elytra $43 \times ; 10$ - abdomen $43 \times$. 
than at base; antennomeres IV-X short, wider than long; antennomere XI truncate diagonally, wider than long, two thirds length of X. Mentum subquadrate, flat, rough, with anterior margin concave (Fig. 6).

Thorax (Figs 7-8). Pronotum narrow, subquadrate, as wide as long, lateral margins serrate, subparallel on anterior half, constricted at base, widest at midpoint, slightly tapering towards base (Fig. 7). Anterior margin nearly straight, anterior angles right to obtuse, disc higher than lateral margins, delimited by two parallel longitudinal keels over entire length of pronotum, slightly converging at base; punctation shallow, coalescent, giving reticulate appearance, posterior margin shorter than anterior margin, straight, posterior angles pointed, protruding. Prosternum oblique from anterior margin to prosternal process, truncate behind procoxae (Fig. 8). Prosternal punctures separated by one to three puncture diameters.

Elytra (Fig. 9) with base narrow, not carinate, widest before midpoint, five times greater than width of base; each elytron with two discal sharp keels and ridge-shaped lateral margin (third keel), only second keel reaching elytral apex; elytral punctation strong, foveolate, dense, coalescing, occupying entire intervals. First elytral interval narrow with two rows of punctures, second, third intervals twice as wide as first, with three to four rows of punctures; pseudopleuron with four rows of punctures (Fig. 10); epipleuron delimited throughout, with one row of punctures, margin forming keel in apical third (Fig. 10). Abdominal ventrites with small, shallow, dense punctures, separated by less than one puncture diameter.

Legs slender, covered with mixture of stout, fine golden setae. Femora longer than tibiae (Fig. 10); tibiae with small

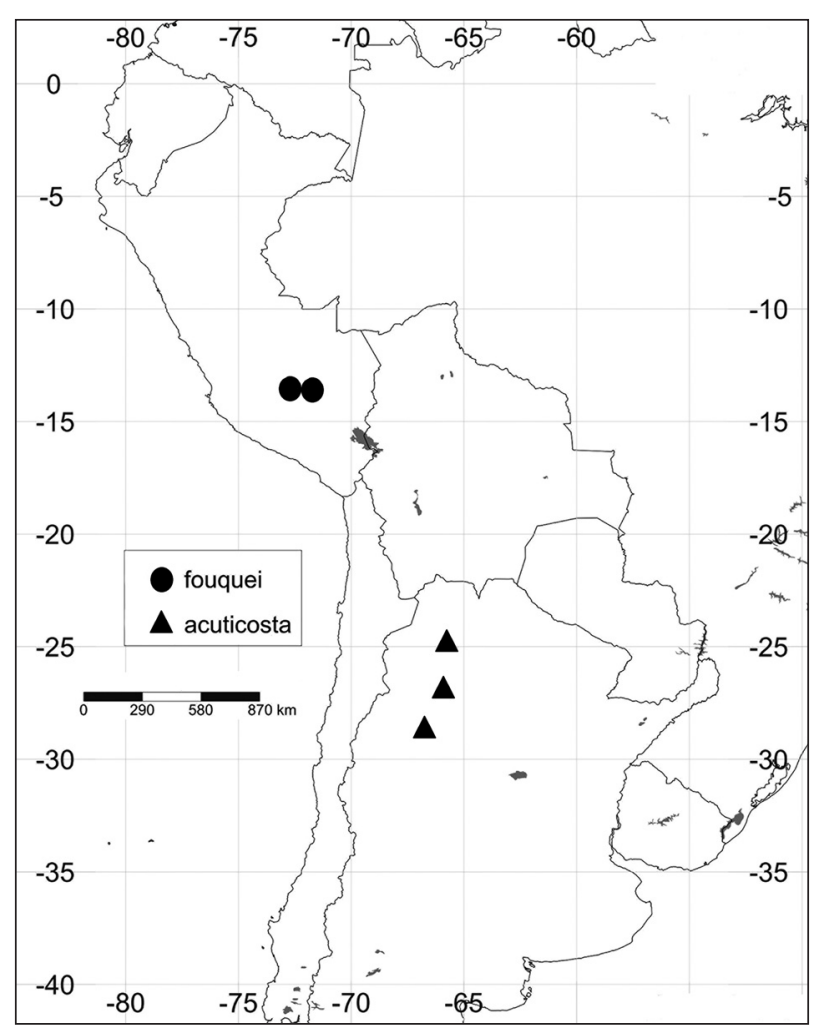

Fig 11. Geographic distribution of Schizaraeus fouquei sp. nov. in southern Peru and S. acuticosta Kulzer, 1955 in northern Argentina. spines on outer surface. Apical pro- and mesotarsomeres longer than III and IV combined; metatarsomere I 1.5 times as long as metatarsomere II; apical metatarsomere as long as II and III combined.

Female genitalia not dissected but ovipositor exposed externally in the paratype used for SEM (IADIZA): coxites with lobes 2-4 fused, basal lobe not extended over paraproct, baculi transverse, length paraproct / coxite short (P/C $\leq 1.2$ ) (Doyen 1994: Fig. 41, Araeoschizus), gonostyli small, sub-apical with setae at apex. Paraprocts with baculi parallel.

Comparative diagnosis. Schizaraeus fouquei sp. nov. and $S$. acuticosta can be separated by the shape of pronotum. Schizaraeus acuticosta has pronotum with lateral margins curved in anterior $2 / 3$ and narrowed in posterior third, anterior angles rounded and posterior angles straight (Fig. 1). On the other hand, S. fouquei sp. nov. has lateral margins of pronotum subparallel in anterior half and constricted at base, anterior angles straight and posterior angles pointed and protruding (Fig. 7).

Etymology. The species name is a tribute to the Czech entomologist René Fouquè (1980-2016) (SEKERKA 2017) for his contribution to the knowledge of the Stenosini and particularly, for his collaboration in the identification of this species.

Distribution. The species is known only from two localities in the high Andean Mts. of southern Peru (Fig. 11) belonging to the biogeographic province of Puna (MoRRONE 2014).

\section{Discussion}

Taking into account the description of this new species and the contributions to the knowledge of Stenosini after Kulzer's (1955) description of Schizaraeus (MEDVEDEV 1996, NABOzHENKo et al. 2016, AALBu et al. 2017), the genus Schizaraeus is redefined by the following combination of characters: head with three keels on top, two lateral and one sagittal; eyes round and not divided, delimited dorsally and ventrally by longitudinal keels; antenna with antennomere III as long as IV-VI combined and antennomere $\mathrm{XI}$ two thirds length of X; pronotum with two longitudinal keels; elytron with three complete keels, two discal and one marginal; epipleuron delimited by a keel only on apical third; ten elytral rows of punctures distributed as following: first elytral interval (two rows), second elytral interval (three to four rows), pseudopleuron (four rows), and epipleuron (one row).

The most recent key to the subtribes and genera of world Stenosini (AALBU et al. 2017) indicates at couplet 30 that in Schizaraeus antennomere III is equal to antennomeres IV-VII combined, but according to our observations presented here it should be modified as follows:

30 Antennomere III equal to next three antennomeres combined. Schizaraeus Kulzer, 1955

- Antennomere III not equal to next three antennomeres combined.

Both species of Schizaraeus are separated by about 1300 $\mathrm{km}$ air distance and inhabit semi-arid habitats at eastern 
slopes of the Andes: Puna and Monte. This pattern of distribution coincides with a recently defined generalised track named South American transition zone (MARTínEZ et al. 2017), which links both Monte and Puna biogeographic provinces (MorRone 2014). This track indicates the existence of an ancestral biota posteriorly fragmented by geologic or tectonic events (MoRrone \& EsCALANTE 2009).

Concerning the remaining genera of South American Stenosina, Ecnomoderes is endemic to Argentinean Monte biogeographic province east of the Andes, Grammicus inhabits coastal deserts of Peru and north-central Chile west of the Andes (KASZAB 1969), and Renefouqueosis is restricted to inter-Andean dry forests in northern Peru (AAlbu et al. 2017).

\section{Acknowledgements}

AEGM thanks FONDECYT, Peru for subsidizing the research internship titled 'Implementación de investigaciones sobre Sistemática de tenebriónidos sudamericanos (Coleoptera, Tenebrionidae)' carried out at IADIZA (Mendoza, Argentina) on September 3-16, 2017. Research by GEF was supported by CONICET, Argentina and NSF DEB-1754630. To Silvina Lassa for help with preparing SEM photos (MEBYM - Laboratorio de Microscopía Electrónica de Barrido y Microanálisis IANIGLA - CONICET Mendoza). Rolf Aalbu, Luboš Purchart and Lukáš Sekerka reviewed the manuscript and gave suggestions for improving this paper. We also thank V. Manuel Diéguez M. for effort and dedication during his collecting trips.

\section{References}

AALBU R., SMITH A. D., KANDA K. \& BOUCHARD P. 2017: Renefouqueosis peruviensis, a new genus and species of Stenosini (Coleoptera: Tenebrionidae) from Peru with a key to the Stenosini of the World and notes on the genera Anchomma and Fitzsimonsium. Acta Entomologica Musei Nationalis Pragae 57: 313-330.

BOUSQUET Y., THOMAS D. B., BOUCHARD P., SMITH A. D., AALBU R. L., JOHNSTON A. \& STEINER W. E. 2018: Catalogue of Tenebrionidae (Coleoptera) of North America. ZooKeys 728: 1-455.
DOYEN J. T. 1994: Cladistic relationships among Pimeliinae Tenebrionidae (Coleoptera). Journal of the New York Entomological Society 101: 443-514.

HADLEY A. 2006: CombineZM public domain image processing software. Available on: http://www.hadleyweb.pwp.blueyonder.co.uk/ CZM/combinezm.htm (accessed and downloaded on 11 $1^{\text {th }}$ June 2009).

KASZAB Z. 1969: The scientific results of the Hungarian Soil Zoological Expeditions to South America. 17. Tenebrioniden aus Chile (Coleoptera). Opuscula Zoologica (Budapest) 9: 291-337.

KULZER H. 1955: Neue Tenebrioniden aus Südamerika. Elfter Beitrag zur Kenntnis der Tenebrioniden. Entomologische Arbeiten aus dem Museum Georg Frey 6: 479-485.

MARTÍNEZ G. A., ARANA M. D., OGGERO A. J. \& NATALE E. S. 2017: Biogeographical relationships and new regionalisation of high-altitude grasslands and woodlands of the central Pampean Ranges (Argentina), based on vascular plants and vertebrates. Australian Systematic Botany 29: 473-488.

MATTHEWS E. G., LAWRENCE J. F., BOUCHARD P., STEINER W. E. \& ŚLIPIŃSKI S. A. 2010: Chapter 11.14. Tenebrionidae Latreille, 1802. Pp. 574-659. In: BEUTEL R. G., LESCHEN R. A. B. \& LAWRENCE J. F. (eds): Handbook of Zoology. A Natural History of the Phyla of the Animal Kingdom. Vol. IV - Arthropoda: Insecta. Part 38. Coleoptera, Beetles. Vol. 2: Systematics (Part 2). Walter de Gruyter GmbH \& Co., Berlin/New York, xiii + 786 pp.

MEDVEDEV G. S. 1996: New data on systematics of darkling beetles of the tribe Stenosini (Coleoptera, Tenebrionidae). Entomological Review 75: 101-124.

MORRONE J. J. 2014: Biogeographical regionalisation of the Neotropical region. Zootaxa 3782: 1-110.

MORRONE J. J. \& ESCALANTE T. 2009: Diccionario de Biogeografia. Las Prensas de Ciencias, Facultad de Ciencias, UNAM, México, D.F., 230 pp.

NABOZHENKO M., KIREJTSHUK A., MERKL O., VARELA C., AALBU R. \& SMITHA. 2016: Caribanosis gen. nov. from Hispaniola (Pimeliinae: Stenosini) with taxonomic notes on the tribes Belopini and Stenosini (Coleoptera: Tenebrionidae). Annales Zoologici 66: 567-570.

PAPP C. S. 1981: Revision of the genus Araeoschizus LeConte (Coleoptera: Tenebrionidae). Entomologische Arbeiten aus dem Museum Georg Frey 29: 273-420.

SEKERKA L. 2017: In memoriam Ing. René Fouquè 10.iv.1980-22. xi.2016. Acta Entomologica Musei Nationalis Pragae 57: 309-312.

SHORTHOUSE D. P. 2010: SimpleMappr, an online tool to produce publication-quality point maps [retrieved from http://www.simplemappr. net.; accessed on $5^{\text {th }}$ May, 2018]. 
